\title{
ДІАГНОСТИКА ТА ЛІКУВАННЯ ГРИПУ: СУЧАСНІ КЛІНІКО-ПАТОГЕНЕТИЧНІ АСПЕКТИ
}

Буковинський державний медичний університет

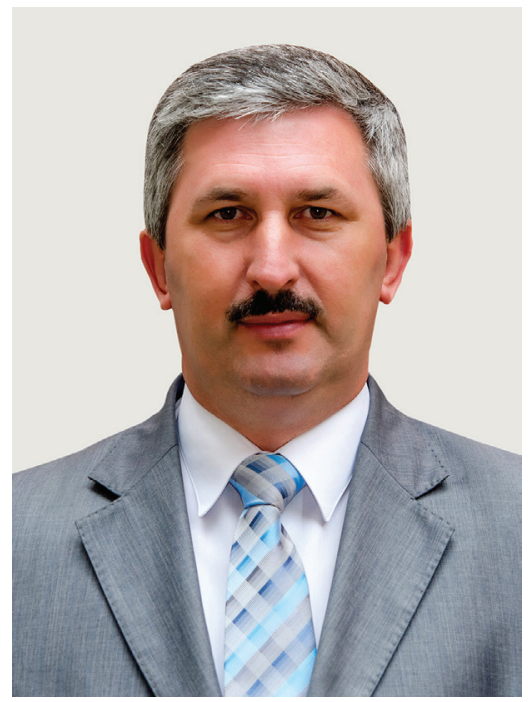

Проаналізовано результати сучасних вірусологічних досліджень глобальної циркуляції вірусів грипу, їх генетичних різновидів. Детально висвітлено клінічні особливості сезонного і пандемічного грипу. Акцентовано на імунопатогенетичних механізмах ускладнених і фратальних випадків інфекції. Обговорено аспекти ефрективного лікування з урахуванням засад доказової медицини. Наголошено на різновекторних принципах профрілактики й запобігання захворювань, спричинених вірусами грипу людини.

Ключові слова: моніторинг, епідемія, грип A/H1N1, вірус-асоційовані пневмонії, діагностика, лікування, доказова медицина.

За останнє десятиріччя українці вже вдруге стають свідками вкрай несприятливої епідемічної ситуації, спричиненої вірусом пандемічного грипу A/H1N1. Станом на 19 лютого поточного року в Україні вже зареєстровано більше 3,8 млн хворих на грип і гострі респіраторні вірусні інорекції (ГРВІ), а загалом перехворіло 9,9 \% населення країни. На жаль, з початку епідемічного сезону в Україні, за оперативними даними, зареєстровано 319 лабораторно підтверджених летальних випадків від грипу, у т.ч. 5 дітей віком до 17 років та 2 випадки серед вагітних. За медичною допомогою своєчасно звернулася лише третя частина померлих. Проведений аналіз летальних випадків показав, що всі померлі не мали щеплень проти грипу. На Буковині з початку епідемічного сезону зареєстровано 80971 випадок грипу та інших ГРВІ, загинуло 12 осіб [1].

Проблема грипу навіть у світовому масштабі далека від остаточного вирішення. Це пов'язано з феноменом надзвичайної генетичної мінливості та реасортації збудника. Так, національні центри з контролю за циркуляцією вірусів грипу 77 країн Європи та Америки перманентно моніторують генетичні різновиди збудників та надають дані до всесвітнього ресурсу FluNet в режимі реального часу [2].

Грип - це гостра убіквітарна висококонтагіозна вірусна хвороба з глобальною циркуляцією вірусів, схильністю до пандемічного поширення, яка характеризується раптовим початком, гарячкою, інтоксикацією, ознаками трахеобронхіту; супроводжується транзиторною імунною диссрункцією, на тлі якої можливий розвиток вірус-асоційованих бактерійних пневмоній, інших грізних вторинних ускладнень і навіть летальний кінець.

Збудники грипу належать до родини Orthomyxoviridae та різних родів Influenzavirus A, В і С. Доведено, що геном вірусів А і В налічує 8 фрагментів РНК, геном вірусу C - 7 фррагментів відповідно. Власне антигенностабільний рибонуклеопротеїн (S-антиген), утворений фрагментами РНК та загальною білковою оболонкою, детермінує родову належність збудника. Кожен ген закодовано на синтез відповідного білка і відтворення РНК віріону. Гени і білки вірусу мають однакові назви і позначаються латинськими літерами, тому в спеціальній науковій літературі оперують такими символами: гени PB1, PB2, NA, NP, HA, M, NS (мал. 1).

Незважаючи на таку складну будову, вірус грипу надзвичайно малий за розміром, його можна побачити лише під електронним мікроскопом за збільшення в 300-500 тис. разів. 


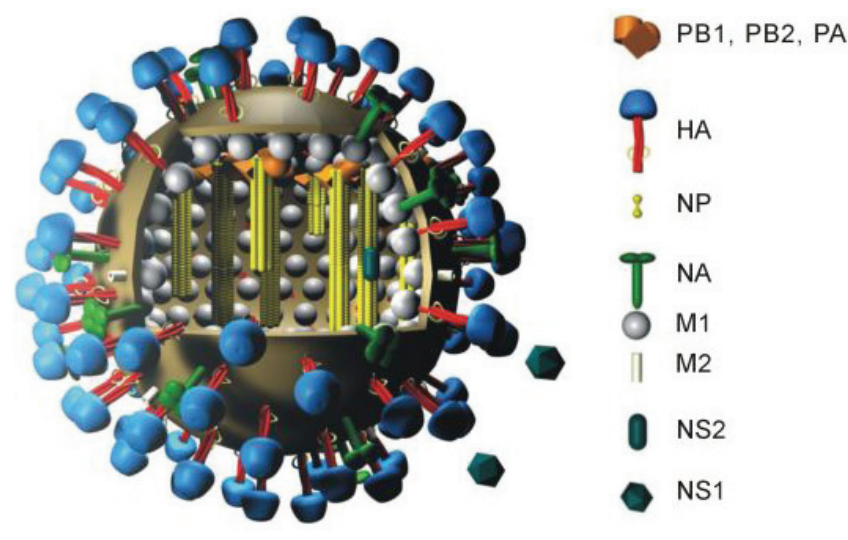

Мал. 1. Генетична структура збудника грипу А [3].

Віруси грипу постійно змінюються за допомогою процесу, званого «антигенний дрейфр. Він полягає у випадковому накопиченні мутацій в генах гемаглютиніну (НА) і в меншій мірі нейрамінідази (NA), які розпізнаються імунною системою. Це найбільш яскраво проявляється у вірусах грипу А. Як і у випадку з усіма РНК-вмісними вірусами, мутації вірусів грипу відбуваються часто, так як механізм реплікації вірусу не володіє коригуючим інструментом. Коли такі зміни викликають мутації в антигенних сайтах генів HA або NA, що знижують або інгібують зв'язування 3 нейтралізуючими антитілами (основу для усунення інфекції в індивідуума), вірус може «ухилитися» від імунної системи $[4,5]$.

Цей процес пояснює виникнення епідемій сезонного грипу, які можуть відрізнятися за ступенем тяжкості і найбільш уразливими віковими групами. Антигенний дрейфр в NA може призвести до резистентності до інгібіторів нейрамінідази. Антигенний дрейфр може також дозволити вірусу перетнути міжвидовий бар'єр і перейти до нового хазяїна.

ще більшою проблемою громадської охорони здоров'я є процес антигенного зсуву, або рекомбінація, завдяки якій відбувається комбінування як мінімум двох різних вірусів, що призводить до заміни НА (наприклад, Н3 замінюється на Н5) та, отже, до утворення мозаїчного вірусу. Це явище може виникати, коли клітину інсрікують два різних віруси грипу, відповідно під час реплікації відбувається обмін сегментами геному [6].

Свині можуть бути заражені як вірусами грипу тварин (свинячим і пташиним), так і вірусом грипу людини. Тому організм свині вважається потенційно найсприятливішим, в якому відтворюється вірус з пандемічним потенціалом. Рекомбінація генома також характерна для водоплавних птахів, особливо качок, з ознаками хвороби, які, хоча і зрідка, виділяють вірус з фекаліями упродовж декількох місяців.
Віруси, що виникають у результаті антигенного зсуву, можуть спричиняти пандемію, так як вони з'являються раптово і в популяціях, проти яких жодна з існуючих вакцин не забезпечує захист. Вірус Н2, який з'явився в 1957 р. (A/H2N2, «азіатський грип»), і вірус Н3, який з'явився в 1968 р. (A/H3N2, «гонконзький грип»), сорормувалися 3 вірусів грипу, які циркулюють серед птахів. Ґрунтуючись на уроках історії, пандемії грипу можна очікувати, в середньому, 3-4 рази на сторіччя. Поступова мінливість вірусу типу В спричинює виникнення епідемії 1 раз на 3-4 роки [7].

Віруси грипу володіють слабкою стійкістю до дії орізичних і хімічних фракторів та руйнуються за кімнатної температури впродовж декількох годин, в той же час за низьких температур (від $-25^{\circ}$ до $-70{ }^{\circ} \mathrm{C}$ ) зберігаються декілька років. Швидко гинуть за нагрівання, висушування, під впливом дезінфекційних засобів (фрормалін, спирт, луг, кислоти). В аерозолях інактивуються під дією малих доз хлору, йоду, озону, ультрасріолетового випромінювання.

Епідеміологія сучасного грипу. Джерелом збудника $€$ хвора людина, а подеколи - інфріковані грипом тварини (птахи, свині, коні). Інфрікувальна доза є вкрай низькою і становить 0,0001 мл назального секрету, тому виразність катарального синдрому визначає рівень епідемічної небезпеки хворої особи. На сьогодні не виключено можливості довічної персистенції вірусу грипу. Хворі на грип зі слабкою інтоксикацією становлять найбільшу епідемічну небезпеку, оскільки продовжують вести активний спосіб життя, інфікуючи велику кількість осіб. Основний механізм передачі - аерозольний. Під час кашлю, чхання велика кількість збудника потрапляє у повітря, а звідти - в дихальні шляхи людей, які оточують хворого, особливо в місцях великого скупчення (громадський транспорт, кінотеатри, театри, дитячі заклади). Контактно-побутове зараження також має істотну роль та реалізується через предмети домашнього вжитку - вологі брудні рушники, використані медичні маски, посуд, грошові банкноти, дверні ручки, дитячі іграшки. Сприйнятливість до вірусів грипу практично абсолютна: найвищі показники морбідності у дітей до 14 років.

Епідемії грипу тривають від 3 до 6 тижнів холодної пори року. Примітним є паралельне зростання захворюваності на аденовірусну, респіраторно-синцитійну, риновірусну і коронавірусну інорекції впродовж епідемічного сезону грипу.

Станом на першу декаду лютого поточного року, 31 з 50 держав-членів, які повідомили епідеміологічні дані 3 нагляду за грипоподібними захворюваннями (ГПЗ) і гострими респіраторними інфекціями (ГРІ), зазначила різке зростання морбідності; 34 країни повідомили про виявлення вірусу грипу в зразках клінічного матеріалу, 
отриманого за останній тиждень січня поточного року, що свідчить про підвищення активності грипу в Європейському регіоні ВООЗ у цілому. Білорусь, Греція, Ірландія і Мальта вказали на активність грипу високої інтенсивності; Україна, Фінляндія та Росія повідомили про дуже високу активність. Переважають A/H1N1 pdm09 віруси, становлячи 61 \% випадків грипу в Європейському регіоні ВОО3 (мал. 2). Саме генетичні різновиди цього вірусу відповідають за збільшення числа випадків тяжкого грипу, в основному в осіб віком 15-64 роки.

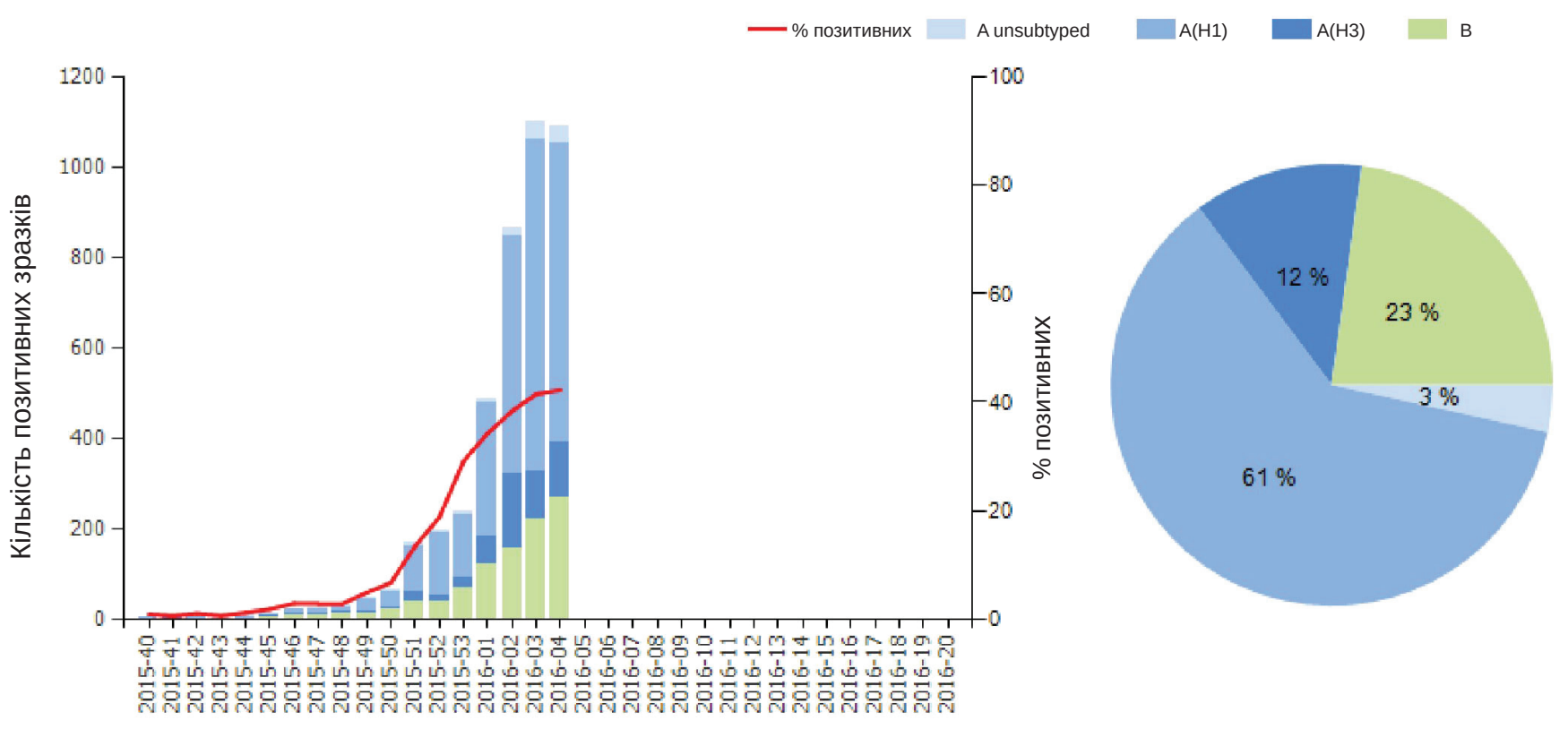

Мал. 2. Дані моніторингу циркуляції вірусів грипу в Європі [2].

Патогенез грипу. Вхідними воротами з високою тропністю до збудника є клітини циліндричного епітелію верхніх і нижніх дихальних шляхів, включаючи бронхіоли 3-го порядку. Умовно в патогенезі грипу виділяють такі фрази:

1. Проникнення і репродукція вірусу в епітеліоциmax: для того, щоб відбулося зараження, вірус повинен «подолати» фрактори неспецифрічної резистентності дихальних шляхів. Після проникнення перших вірусних частинок у клітини ініціюється синтез інтерферону, який надходить до міжклітинної рідини з основним завданням захисту інтактних клітин. Перший цикл реплікації вірусу триває близько 4-6 годин, а швидкість розмноження надзвичайно висока - наприкінці першої доби фрормується $10^{23}$ зрілих віріонів. Ця фраза відповідає короткому інкубаційному періоду - від декількох годин до 2-3 діб.

2. Вихід вірусу, руйнування уражених клітин: остаточне фрормування вірусних частинок відбувається за участю мембрани клітини на її поверхні. Важливу роль у звільненні вірусу відіграє нейрамінідаза, яка запобігає агрегації дочірніх віріонів. Загибель уражених і зруйнованих епітеліоцитів обумовлена не стільки цитопатогенною дією, скільки нездатністю клітини повністю відновитися після активного споживання її ресурсів у процесі синтезу всіх компонентів вірусного нуклеокапсиду.

Масовий апоптоз інфрікованих епітеліоцитів трахеї, бронхів супроводжується вкрай високим рівнем вірусемії й токсинемії. Тому клінічно явища токсикозу при грипі передують появі катаральних симптомів, настаючи раніше - у межах від 3 до 24 год від початку грипу.

3. Розвиток вірусемії, токсинемії, катарального синдрому: відповідає 1-ій добі захворювання, зумовлений некрозом і десквамацією епітелію дихальних шляхів. Клінічно для цього періоду характерним є подразнення нервових закінчень і рефрлекторний сухий надсадний кашель, який супроводжується відчуттям дряпання, печіння за грудниною. Катаральний синдром на початку недуги не є вираженим, супроводжується незначними серозними виділеннями 3 носа, утрудненим носовим диханням, явищами трахеобронхіту. Катаральний синдром триває 7-10 діб, найдовше турбує кашель, який поступово змінює характер із сухого на вологий. Зони значної десквамації епітелію призводять до «оголення» підслизового шару. Приєднання бактерійної фрлори на тлі транзиторної дисфункції імунної системи сприяє 
розвитку вторинних бактерійних ускладнень. Упродовж перших 3 діб в організмі переважають механізми неспецифрічного протиінфекційного захисту (інтерферон, тканинні інгібітори, запальна реакція). Вірус грипу чинить виражену імуносупресивну дію, пригнічуючи позитивний хемотаксис та фрагоцитоз нейтрофрілів. Синтез специфічних протигрипозних антитіл розпочинається не раніше 5-го дня хвороби, тому саме період з 3-го по 5-ий дні є найбільш ризикованим щодо виникнення вторинно-інорекційних ускладнень грипу. Відповідно до цих змін, розрізняють неспецифрічну і специсічну фрази імунітету. Схематично їх можна показати у формі двох кривих (мал. 3).

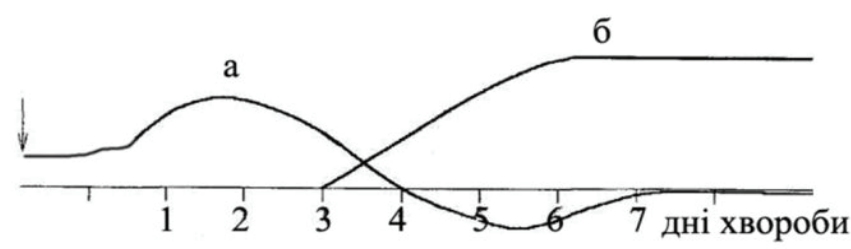

Мал. 3. Схема захисних реакцій при грипі: а - неспецифічні, б - специфічні (за М.А. Андрейчином).

Неважко зрозуміти, що найуразливішою буде 3-4-а доба, яка припадає на перехрещення вказаних кривих. У цей час неспецифічний захист організму вже виснажився, а специфічні антитіла щойно почали утворюватись і концентрація їх ще недостатня для подолання вірусу грипу.

4. Реконвалесценція, фрормування імунітету: оскільки протигрипозні антитіла починають визначатися у сироватці хворих не раніше 7-ої доби хвороби, їх участь в одужанні мінімальна. Однак захворювання перебігає легше, якщо в крові хворого містяться антитіла (після вакцинації або перенесеного раніше грипу) проти відповідних антигенних детермінант вірусу. У випадку інфрікування «новим» для організму вірусом, реконвалесценція відбуватиметься за участю неспецифічних фракторів захисту і «включення» клітинного імунітету. Цитотоксичні Т-лімфоцити (Т-кілери) забезпечують лізис клітин-мішеней, уражених вірусом; декретують лімфокіни та активують макрофраги. Істотна роль в інактивації вірусу належить секреторним IgА антитілам, швидкість секреції яких перевищує швидкість утворення сироваткових антитіл В-лімфоцитами - плазматичними клітинами. Вже через декілька днів від початку хвороби розпочинається регенерація епітелію респіраторного тракту. Циркулюючі антитіла (віруснейтралізувальні і комплементзв'язувальні) захищатимуть від повторного інсрікування тим же субтипом вірусу.

Істотна інтоксикація призводить до зниження тонусу судин водночас з підвищенням їх ламкості, що може проявлятися клінічно у вигляді носових, ясневих кровотеч. Цитопатична, вазопаралітична та імуносупресивна дії збудника зумовлюють розвиток грізних ускладнень 3 боку серцево-судинної та нервової систем. Виражений запальний процес верхніх дихальних шляхів позначається на функції зовнішнього дихання, оксигенації крові й збагаченні киснем органів і тканин. Явища системного токсикозу і геморагічного капіляротоксикозу можуть призводити до геморагічного набряку легень, мозку та його оболонок, арахноїдиту.

Теперішній грип $є$ тяжким інфекційним захворюванням, який клінічно наразі перебігає дещо відмінно від того, що клініцисти спостерігали десяток років тому. Практично у 40 \% інфікованих пандемічним каліфорнійським вірусом грипу виникають ускладнення, насамперед вірус-асоційовані пневмонії (ВАП). Розрізняють три типи ВАП: 1-го типу - детермінують як вірусну, інтерстиційного характеру, з бурхливим, часто фратальним перебігом, неефективністю оксигенотерапії, високою летальністю; 2-го типу - вірусно-бактерійної природи, що розвивається наприкінці першого тижня недуги, частіше спричиненої грампозитивними мікроорганізмами, 3 типовою клінічною картиною і фрізикальними даними; 3-го типу - формується на другому тижні від початку вірусної інфрекції, частіше зумовлена грамнегативними збудниками [8].

Токсико-алергійні й автоімунні реакції у молодих осіб за пандемічного грипу $є$ фракторами додаткового ушкодження тканин легень, що викликано «цитокіновим штормом» у зв'язку з неконтрольованою секрецією медіаторів запалення [9]. Найвищі показники ранньої летальності від грипу спричинені респіраторним дистрес-синдромом.

Клініка. Грип починається гостро, раптово. Інкубаційний період короткий, триває від декількох годин до 2 діб. Навідними симптомами хвороби є гострий початок з ознобом, наступним швидким підвищенням температури тіла до $38,5-40,0{ }^{\circ} \mathrm{C}$, проявами загальної інтоксикації. Опорні симптоми: біль голови, переважно в лобній і скроневій ділянках, надбрівних дугах, біль при рухах очними яблуками (ретроорбітальний), натисканні на них, сильний біль у м'язах, суглобах, слабкість, розбитість, світлобоязнь, пітливість та інші явища загальної інтоксикації, які змушують хворого злягти в ліжко вже у перші години захворювання. Хворі вказують також на сухий болісний кашель, відчуття печії, подряпування за грудниною, закладеність носа (синдром ураження респіраторного тракту). Через 12-24 год від початку захворювання з'являється й зростає ексудативний компонент: кашель стає менш надсадним, вологим, з'являються серозні, серознослизові виділення 3 носа. 
При об'єктивному обстеженні хворого спостерігаються почервоніння та одутлість обличчя, ін'єкція судин склер, помірний ціаноз губ, герпетичні висипання, дисрузне почервоніння слизової оболонки ротоглотки, «зернистість» м'якого піднебіння, особливо при грипі, викликаному вірусом типу В (симптом Морозкіна), деколи - дрібні крововиливи на піднебінні, набряклість і почервоніння слизової оболонки носа, підвищена вологість шкіри, брадикардія, зниження АТ, приглушення I тону серця на верхівці, акцент II тону над легеневою артерією. За неускладненого грипу гарячка триває впродовж 2-4 днів (у 80-85 \% хворих), у поодиноких випадках - більше 5 днів. Двогорба температурна крива зустрічається зрідка - у 5-10 \% хворих [10].

У міжепідемічний період грип перебігає значно легше, ніж під час епідемії, та за своїми клінічними проявами мало чим відрізняється від гострих респіраторних захворювань іншої етіології. Тяжчий перебіг грипу спостерігається в перші 2 тижні епідемії.

Наводимо ймовірні клінічні сценарії грипу A/H1N1 [11]:

1. Неускладнений грип:

- Симптоми грипоподібного захворювання: гарячка, кашель, подразнення слизової оболонки глотки (фарингіт), риніт, біль голови, міалгія, загальне нездужання без задишки та утрудненого дихання.

- Шлунково-кишкові порушення, такі як $є$ діарея та/ або блювання, особливо у дітей, однак без ознак зневоднення. Короткочасна діарея пов'язана зі змінами тонусу вегетативної нервової системи внаслідок інтоксикації.

2. Симптоми прогресуючої хвороби:

- Ознаки серцево-дихальної недостатності: задишка, утруднене дихання, кровохаркання чи забарвлене мокротиння, біль у грудях, артеріальна гіпотензія. У дітей - прискорене чи утруднене дихання, ознаки гіпоксії за даними пульсоксиметрії.

- Симптоми, що свідчать про ураження з боку ЦНС: порушення чи втрата свідомості, сонливість чи труднощі при пробудженні після сну; періодичні чи постійні судоми, різка м'язова слабкість чи паралічі.

- Діагностичний висновок про реплікацію вірусу, що триває, чи про вторинну бактерійну інфекцію, що ґрунтується на результатах лабораторних досліджень, або на клінічних ознаках (наприклад, тривалість високої гарячки та іншої симптоматики більше ніж три дні, сепсис, стрімке погіршення загального стану).

- Швидке зневоднення організму: зниження активності, запаморочення, зниження діурезу, психічна загальмованість.

3. Ускладнення чи тяжкі (блискавичні) форми грипу:

- Найчастіші прояви: задишка, утруднене дихання, гіпоксія, ціаноз, зміни з боку ЦНС, рентгенологічні озна- ки пневмонії, різке зневоднення чи ознаки вторинних ускладнень, таких як ниркова чи поліорганна недостатність, септичний шок.

- Загострення супутніх хронічних захворювань, таких як бронхіальна астма, хронічний гепатит чи ниркова недостатність, цукровий діабет чи серцево-судинні порушення, може стати причиною тяжких ускладнень.

До істинних грипозних ускладнень належать токсичний геморагічний набряк легень, міокардит, несправжній круп, набряк-набухання головного мозку, арахноїдит, поліневрит, радикуліт, невралгії різної локалізації, ендокардит, міозит, нефрит, гломерулонефрит (інфекційно-алергічного та автоімунного ґенезу), синдром Гійєна-Барре (перифреричний висхідний параліч м'язів кінцівок).

Друга група ускладнень розвивається в результаті суперінфекції або активації хронічного вогнища інфекції і зумовлена бактерійною флорою: гнійно-некротичний бронхіт, бронхіоліт, вторинні бактерійні пневмонії, емпієма плеври, абсцес легень, пневмоторакс, загострення хронічного обструктивного захворювання легень. Частіше вони розвиваються після 4-го дня хвороби. Стафрілококова пневмонія $€$ найнебезпечнішою, оскільки симптоми можуть бути присутні вже через 2-3 дні від початку захворювання. Турбують задишка, криваве харкотиння, ознаки гіпоксемії та лейкоцитоз у гемограмі. Частими збудниками вторинних пневмоній $€$ метицилінрезистентний стафрілокок, пневмокок, гемофрільна паличка, стрептококи, ентеробактерії. В період реконвалесценції можуть розвинутися гострий синусит, гострий отит, гострий гнійний тонзиліт, фрронтит.

Типовим є «синдром постгрипозної астенії» тривалістю до 1,5 міс., що характеризується загальною слабкістю, пітливістю, зниженим апетитом, безсонням, зниженням уваги, емоційною лабільністю, частим серцебиттям, гіперестезією кистей і стоп, періодичним субсребрилітетом.

Переважна більшість випадків грипу завершуються повним одужанням. За глобальною оцінкою експертів ВОО3, пандемія 2009/2010 рр. у світі призвела до смерті біля 500 тисяч осіб. В Україні було зафіксовано 1128 летальних випадків, показник летальності склав 0,02 \% від усіх захворілих. Понад 80 \% смертей від грипу були зареєстровані серед осіб віком від 18 до 50 років, що характерно для пандемічного каліфорнійського штаму. Так, фратальна двобічна геморагічна пневмонія достовірно частіше розвивалась на тлі супутніх захворювань: хронічних захворювань легень, цукрового діабету, ожиріння, хронічних серцево-судинних захворювань та у вагітних [12].

Як свідчить досвід минулих років, під час сезонного грипу, навпаки, найбільш уразливим є віковий контингент 
осіб старше 65 років. Смертність від грипу A/H3, типу B не перевищує 1-3 випадки на 100 тисяч населення, до групи ризику насамперед відносять осіб похилого і старечого віку з тяжкою коморбідною патологією.

Діагностика грипу під час епідемії не викликає особливих труднощів і базується на клініко-епідеміологічних даних. У міжепідемічний період грип реєструється рідше, переважають випадки легкого клінічного перебігу і його важко дисреренціювати з іншими гострими респіраторними захворюваннями. В таких випадках діагноз можна встановити на основі лабораторних методів:

- люмінесцентної мікроскопії мазків-відбитків із слизової носа, забарвлених акридин-оранжевим, і виявлення РНК вірусів;

- імунофрлуоресценції (експрес-метод) - виявлення антигену вірусу грипу в мазках із слизової носа, із ротоглотки за допомогою фрлуоресціюючих імунних сироваток (типоспецифрічних);

- швидких імунохроматографрічних тестів для якісного виявлення антигенів вірусів грипу А, В у назальному секреті;

- серологічних реакцій (РЗК, РГГА, РНЗ, ІФА з грипозними діагностикумами) методом парних сироваток (першу беруть до 6-го дня хвороби, другу - через 8-14 днів); діагностичне значення має наростання титру антитіл у 4 рази і більше;

- вірусологічного дослідження змивів із ротоглотки, крові з виділенням вірусів грипу на курячих ембріонах, культурі тканин (має переважно ретроспективне значення);

• для ідентифрікації вірусного геному із визначенням типу і субтипу вірусу грипу в клінічних зразках рекомендовано застосовувати зворотну транскриптазну полімеразну ланцюгову реакцію (ЗТ-ПЛР).

Враховують клініко-епідеміологічні критерії діагнозу: контакт із хворим, гострий початок, переважання інтоксикаційного синдрому над катаральним, короткочасну гарячку, катаральний синдром у вигляді трахеїту, наявність зернистості м'якого піднебіння, язичка й дужок.

Належне використання діагностичних тестів, а також своєчасне призначення противірусних засобів можуть пом'якшити клінічний перебіг грипу, зменшити непотрібне діагностичне тестування, тривалість необхідної медичної допомоги і знизити як доречне (з приводу можливих бактерійних ускладнень), так і недоречне застосування антибактерійних лікарських засобів.

Лікування. Хворих на неускладнену фрорму сезонного грипу лікують вдома. Під час гарячкового періоду хворим рекомендується дотримуватись ліжкового режиму. Хворого, якого лікують удома, ізолюють до окремої кімнати. Для нього виділяють окремий посуд, який знезаражують крутим кип'ятком. Для профрілактики гемора- гічного синдрому, особливо хворим старших вікових груп з підвищеним артеріальним тиском, рекомендується призначати вітамін Р (рутин) по 150 мг/добу в поєднанні 3 аскорбіновою кислотою (300 мг/добу).

Провідним напрямком лікування в типових випадках є патогенетична терапія (пероральна детоксикація, жарознижувальні, відхаркувальні засоби). 3 метою детоксикації кількість спожитої рідини має бути такою, щоби під час хвороби добовий діурез був не меншим, ніж зазвичай. Рекомендовано чай з лимоном, малиною, соки-фреш, евкаліптові, чебрецеві, ромашкові настої, лужні мінеральні води 3 молоком. Вагітним при грипі та застудах не можна вживати листя малини, оскільки вони можуть спровокувати спазми матки i, як результат, викликати передчасні пологи. 3 цієї ж причини вагітним не можна вживати ягоди калини.

Одностайної думки щодо доведеної ефективності «імуномодуляторів з протигрипозною активністю» деяких препаратів, з позицій доказової медицини, нині немає («Арбідол», «Аміксин», «Амізон», «Кагоцел», «Імунофан» тощо). Тому доцільність їх використання, на нашу думку, виноситься на розсуд пацієнта та його віри у дієвість медикаменту.

Застосування жарознижувальних препаратів (на основі парацетамолу, ібупрофену) виправдане за умови гіперпірексії або наявності мозкових й серцево-судинних розладів у дозі, що забезпечить поступове зниження температури тіла.

Оскільки температурна реакція має позитивне компенсаторне значення, активує фрагоцитоз, корелює 3 інтерфероноутворенням, шаблонне використання антипіретиків є недоцільним [13]. Застосування ацетилсаліцилової кислоти з цією метою заборонено через провокуючу роль у розвитку смертельно небезпечного синдрому Рея - гострої гепатаргії.

Утруднення носового дихання і закладеність носа зменшують шляхом розпилення у носові ходи судинозвужувальних засобів (широко використовують препарати на основі оксиметазоліну чи ксилометазоліну - «Нази він», «Нок-спрей», «Віброцил», «Фармазолін» та ін.).

Аби зменшити прояви фрарингіту, рекомендовано пом'якшувальні смоктальні таблетовані або інгаляційні засоби з антисептичною дією - «Фарингосепт», «Трахісан», «Інгаліпт», «Орасепт», «Септолете», «Лісобакт», «Каметон». Вагітним слід з обережністю застосовувати таблетки для розсмоктування «Граммідин» і «Септефррил» через відсутність клінічних даних про безпеку застосування.

Широке використання для лікування та профрілактики грипу та інших респіраторних вірусних інсрекцій таких противірусних засобів, як «Оксолінова мазь», «Теброфен» та «Людський лейкоцитарний інтерферон» 
у вигляді носових крапель, з точки зору сучасних принципів медицини, заснованої на доказах, на жаль, не має достатніх наукових підстав, так як їх ефективність не підтверджена результатами контрольованих клінічних досліджень.

Противірусні препарати двох класів мають активність проти вірусів грипу: адамантани, що активні проти вірусів грипу A, та інгібітори нейрамінідази, що активні проти вірусів грипу А і В.

Блокатори М2-каналів вірусу грипу А (амантадин, римантадин) порушують здатність вірусу проникати в клітини і вивільняти рибонуклеопротеїд. Противірусний ефект блокаторів М2-каналів діє тільки стосовно вірусів грипу А. «Ремавір» призначають у перші 24-48 год захворювання дорослим по 100 мг кожні 12 год, тривалість прийому - 3-5 днів.

Інгібітори нейрамінідази (занамівір, озельтамівір) порушують здатність вірусів грипу А і В проникати в епітеліальні клітини, гальмують вихід віріонів із інфікованої клітини, зменшують стійкість віріонів до дії секреторних фракторів резистентності (противірусний ефект). Препарати також зменшують синтез цитокінів, які беруть участь у місцевій і системній реакціях запалення. Занамівір застосовують у вигляді інгаляцій по 5 мг (1 ротадиск) кожні 12 год впродовж 5 днів. Озельтамівір призначають по 1-2 капсулі кожні 12 год впродовж 5 днів. При кліренсі креатиніну менше 30 мл/хв необхідно розглядати можливість зниження дози озельтамівіру. Пацієнтам із тяжким чи прогресуючим перебігом хвороби, котрі не реагують на звичайні схеми, можуть бути показані більш високі дози озельтамівіру (до 150 мг двічі на добу) та більша тривалість курсу терапії.

Занамівір («Реленза») послаблює системний вплив вірусної інфекції і здатен інгібувати відтворення вірусних часток лише на початковій фразі патогенезу грипу (максимальний терапевтичний ефект при вживанні за перших симптомів - упродовж 24-48 год). Препарат діє у позаклітинному просторі, зменшуючи продукцію вірусу та запобігаючи викиду вірусних частинок з клітин епітелію верхніх дихальних шляхів. До занамівіру чутливими $€$ віруси грипу типу A та $B$.

Всіх госпіталізованих пацієнтів з підозрою на грип A/H1 доцільно лікувати противірусними препаратами.

До осіб з високим ризиком ускладнень грипу, в яких розглядається противірусна терапія, належать:

- носії генів серповидноклітинної анемії та інших гемоглобінопатій;

• особи, які мають імуносупресивні розлади чи отримують імуносупресивну терапію;

- особи із захворюваннями, які вимагають тривалої аспіринотерапії;

- ВІЛ-інфріковані;
- особи з хронічною нирковою недостатністю;

- хворі на епілепсію та інші нервово-м'язові розлади;

- онкохворі;

- особи з хронічними хворобами серця;

- хворі на бронхіальну астму або інші хронічні хвороби легень;

- дорослі віком понад 65 років;

- нещеплені діти віком 12-24 міс.;

- мешканці закладів закритого типу (дитбудинків, геріатричних пансіонатів тощо).

Застосовувати інгібітори нейрамінідази в масовому порядку для профрілактики без особливих показань ВООЗ не рекомендує у зв'язку з ймовірним формуванням резистентності вірусів грипу до цих препаратів.

При первинній медичній допомозі або першому контакті з медичним співробітником (наприклад, при наданні невідкладної допомоги) може бути використано три різні стратегії лікування антибактерійними лікарськими засобами: відмова від антибактерійних лікарських засобів; відкладене у часі призначення антибактерійних лікарських засобів; негайне призначення антибактерійних лікарських засобів (табл. 1) [11].

Спільне рішення лікаря і пацієнта стосовно вибору стратегії призначення антибактерійних лікарських засобів залежить як від оцінки лікарем ризику розвитку ускладнень у разі утримання від антибіотикотерапії, так і від очікувань пацієнта відносно застосування антибактерійних препаратів. Перевага відкладеного призначення порівняно зі стратегією відмови від призначення полягає у тому, що воно передбачає призначення антибіотиків (виписаний рецепт, розрахована доза та кратність прийому) для незначної кількості пацієнтів, у яких можуть розвинутися ускладнення, і тому, що пацієнти, які очікують призначення антибактерійних препаратів, можуть бути більш схильними погодитися з таким курсом лікування, ніж з повною відмовою від їх застосування. Саме тому відкладене призначення $€$ важливою стратегією лікування з метою скорочення кількості призначення недоречних антибактерійних лікарських засобів.

На практиці антибіотикотерапія повинна призначатися вельми розважливо, при чітких показаннях до застосування: 1) позитивній бактеріологічній культурі харкотиння, назального секрету (бактерійні ускладнення у вигляді пневмонії, синуситу, гострого гнійного бронхіту, тонзиліту тощо); 2) вторинній гіпертермії на 5-ий день перебігу хвороби; 3) гіпертоксичній формі з енцефалітними проявами, що починається 3 пневмонії; 4) грипі у вагітних; 5) грипі у дітей перших двох років життя; 6) тяжкій хронічній коморбідній патології; 7) грипі у різко ослаблених осіб старечого віку. 
ПЕРЕДОВА СТАТТЯ

Таблиця 1

Рекомендації стосовно антибіотикотерапії

\begin{tabular}{|c|c|}
\hline Антибіотикотерапія & Поради \\
\hline Непоказана & $\begin{array}{l}\text { Запевнити, що антибіотики не потрібні в даний час, оскільки вони можуть незначною мірою } \\
\text { вплинути на перебіг хвороби, але можуть спричинити побічні реакції (наприклад, діарею, } \\
\text { блювання, висипку тощо). } \\
\text { Призначити повторний клінічний огляд в разі, якщо стан пацієнта погіршується або відсутня } \\
\text { динаміка }\end{array}$ \\
\hline Можна відтермінувати & $\begin{array}{l}\text { Запевнити, що антибіотики не потрібні в даний час, оскільки вони можуть незначною мірою } \\
\text { вплинути на перебіг хвороби, але можуть спричинити побічні реакції (наприклад, діарею, } \\
\text { блювання, висипку тощо). } \\
\text { Надати поради щодо того, коли розпочати прийом антибіотиків (симптоми не зникають про- } \\
\text { тягом двох діб або стан погіршується). Рецепт видати одразу. } \\
\text { Призначити повторний клінічний огляд в разі, якщо стан пацієнта погіршується або відсутня } \\
\text { позитивна динаміка через дві доби від початку прийому антибіотиків. }\end{array}$ \\
\hline Негайно призначити & 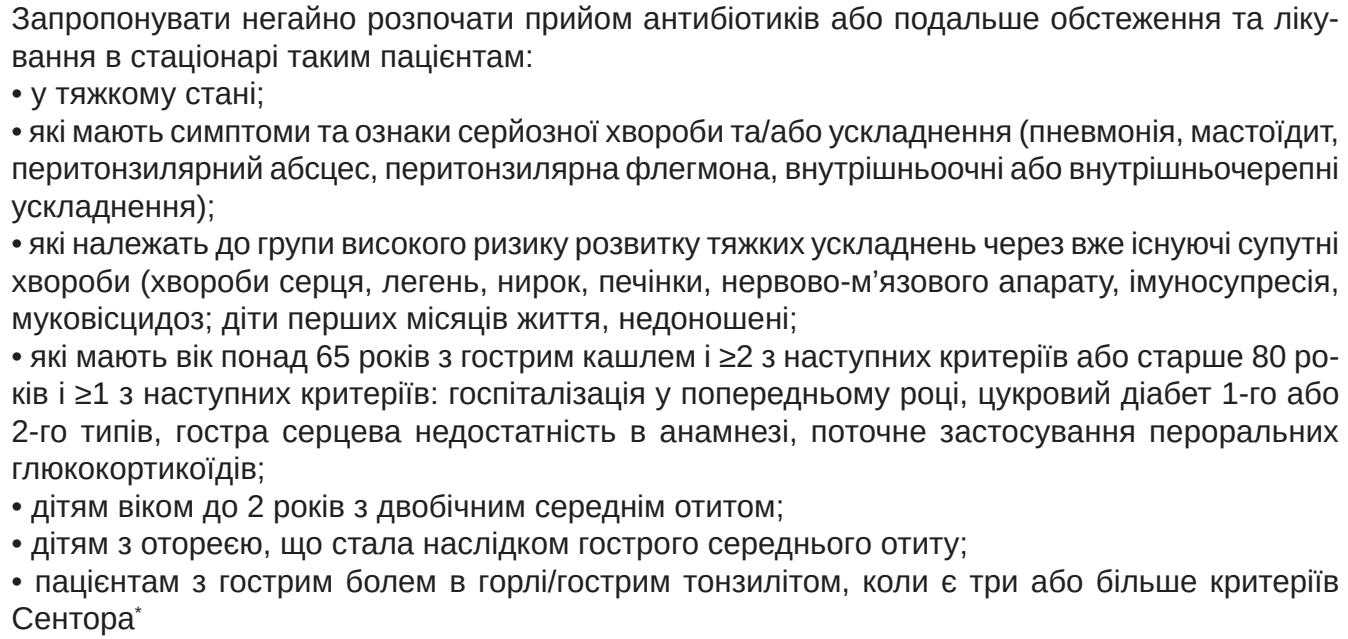 \\
\hline
\end{tabular}

"Критерії Сентора: набряклість і наявність ексудату на мигдаликах; збільшені і болючі передньошийні лімфатичні вузли; гарячка $>38^{\circ} \mathrm{C}$ в анамнезі; відсутність кашлю.

Високу антибактерійну активність і широкий спектр дії, включаючи полірезистентні грамнегативні та грампозитивні бактерії, мають «респіраторні» фрторхінолони - левосрлоксацин, гатифрлоксацин, геміфрлоксацин, моксифрлоксацин. Широко використовують цефалоспорини 3-4-го покоління (цефтазидим, цесрепім, цефтриаксон), комбінації ампіцилінів з інгібіторами $\beta$-лактамаз (амоксиклав), карбапенеми (меропенем, дорипенем), макроліди (рокситроміцин, мідекаміцин), а також аміноглікозиди 3-го покоління (амікацин, нетилміцин). У випадку ускладнення, спричиненого метицилінрезистентним стасрілококом (MRSA), рекомендують ванкоміцин або лінезолід.

Негативними ефектами від необґрунтованої антибіотикотерапії $€$ пригнічення синтезу протигрипозних антитіл, посилення алергізації інфрікованого грипом організму, дисбіотичних зрушень в екосистемі мікро- біоти слизових оболонок респіраторного й шлунковокишкового тракту.

Показання до госпіталізації [11]:

1. Частота дихання $>30 / x$ в.

2. Частота серцевих скорочень $>130 /$ хв.

3. Систолічний артеріальний тиск <90 мм рт. ст. або діастолічний артеріальний тиск <60 мм рт. ст. (якщо це не $є$ нормою для цього пацієнта).

4. Сатурація кисню $<92 \%$ або центральний ціаноз (якщо особа не має хронічної гіпоксії в анамнезі).

5. Пікова об'ємна швидкість видиху <33 \% від належної.

6. Змінений стан свідомості.

7. Дихальна недостатність $\geq$ II ст.

8. Температура тіла $\geq 38,5^{\circ} \mathrm{C}$, що не піддається корекції лікарськими засобами. 


\section{9. Пацієнт віком $\geq 65$ років.}

10. Епідемічні соціальні покази (проживання в закладах закритого типу; нездатність до самообслуговування, що стала наслідком хвороби).

Профрілактику грипу важливо планувати ще восени, напередодні зимово-весняного періоду. Вибір методу вирішується спільно з сімейним лікарем, на консультації в інфекціоніста в конкретному клінічному випадку індивідуально.

Безапеляційно важливим заходом запобігання поширенню грипу є раннє виявлення хворого, його ізоляція в домашніх умовах або в інфекційному стаціонарі.

Як метод післяконтактної хіміопрофрілактики для осіб з груп ризику можна застосувати озельтамівір по 75 мг один раз на добу дорослим та дітям (залежно від маси тіла) від 30 мг до 75 мг один раз на день; занамівір (два вприскування по 5 мг один раз на день); ремантадин 200 мг на день (дорослі) та до 150 мг дітям від року. Якщо хіміопрофрілактику призначають особам, які мають контакти з інфрікованими грипом на побутовому рівні, противірусні препарати рекомендовано приймати протягом 10 днів. Під час спалаху грипу хіміопрофілактику в закладах закритого типу варто проводити впродовж 14 днів.

Для специфрічної профрілактики грипу проводять щеплення інактивованими грипозними вакцинами цільновіріонними, спліт-вакцинами, субодиничними. Ефективність вакцини проти грипу залежить від віку, імунного статусу й відповідності між циркулюючим і вакцинальним штамом вірусу.

Консультаційна нарада ВООЗ рекомендує для північної півкулі світу в епідемічному сезоні 2015-2016 рр. використовувати вакцини проти таких штамів вірусів грипу: A/California/7/2009(H1N1)pdm09; А/Швейцарія/(H3N2); B/Phuket/3073/2013. До складу чотирьохвалентної вакцини включено вірус, подібний B/Brisbane/60/2008.

Згідно з відомостями Державного реєстру лікарських засобів, в Україні зареєстровано 9 медичних імунобіологічних препаратів для специсрічної профрілактики грипу, штамовий склад яких відповідає рекомендаціям ВООЗ на поточний епідемічний сезон.

Агрипал S 1 - вакцина для профрілактики грипу, очищена, інактивована, у вигляді суспензії для ін'єкцій. Одна доза вакцини (0,5 мл) містить: поверхневі антигени (гемаглютинін і нейрамінідаза): A/California/07/2009(H1N1); A/Perth/16/2009(H3N2); B/Brisbane/60/2008 виробництва «Novartis Vaccines and Diagnostics» (Італія/Іспанія).

Ваксігрип - спліт-вакцина для профілактики грипу інактивована рідка, у вигляді суспензії для ін'єкцій. Одна імунізуюча доза вакцини для дорослих (0,5 мл) містить A/California/7/2009(H1N1)pdm09-похідний штам, A/Texas/50/2012(H3N2)-подібний штам та
B/Massachusetts2/2012 штам виробництва «Sanofi Pasteur» (Франція).

Джисіфлю/GCflu® - спліт-вакцина для профілактики грипу інактивована, у вигляді суспензії для ін'єкцій, виробництва «Грін Крос Корпорейшн», Корея.

Гриппол® нео - вакцина для профілактики грипу тривалентна інактивована субодинична ад'ювантна у вигляді суспензії для внутрішньом'язового і підшкірного введення зі складом: A/California/7/2009(H1N1)-подібний; A/Perth/16/2009(H3N2)-подібний; B/Brisbane/60/2008подібний виробництва ТОВ «ФармаЛайфр» (Україна).

Гриппол® плюс - вакцина для профрілактики грипу тривалентна інактивована полімер-субодинична. Суспензія для внутрішньом'язового і підшкірного введення. Одна імунізуюча доза (0,5 мл) містить: A/California/7/2009(H1N1)-подібний; A/Perth/16/2009(H3N2)-подібний; B/Brisbane/60/2008подібний виробництва ТОВ «Фарма Лайфр (Україна).

Інтанза 9/інтанза 15 - спліт-вакцина для профрілактики грипу інактивована рідка у вигляді суспензії для ін'єкцій по 0,1 мл (1 доза) в одноразових шприцах 3 мікроінжектором № 10 та № 20.

Інтанза 9: одна імунізуюча доза вакцини (0,1 мл) містить: A/California/7/2009(H1N1)pdm09-похідний; A/Victoria/361/2011(H3N2)-похідний; B/Wisconsin/1/2010подібний), похідний В/Hubei-Wujiagang/158/2009.

Інтанза 15: одна імунізуюча доза вакцини (0,1 мл) містить: A/California/7/2009(H1N1)pdm09-похідний; A/Victoria/361/2011(H3N2)-похідний; B/Wisconsin/1/2010подібний, похідний B/Hubei-Wujiagang/158/2009 виробництва «Sanofi Pasteur» (Франція).

Флюарикс ${ }^{\mathrm{TM}}$ - інактивована спліт-вакцина для профрілактики грипу у вигляді суспензії для ін'єкцій по 0,5 мл. Склад антигенів і штами вірусів: A/California/7/2009 (H1N1) pdm09-подібний штам [варіант A/Christchurch/16/2010]; A/Texas/50/2012 (H3N2)-подібний штам [варіант A/Texas/50/2012]; B/Massachusetts/02/2012-подібний штам [варіант B/Massachusetts/02/2012] виробництва «GSK» (Великобританія).

Розвиток імунітету ініціюється з 2-го дня після щеплення, сягає максимуму на 15-30-й день і триває від 6 міс. до року, що зумовлює необхідність щорічної вакцинації. Профрілактична ефективність може становити 70-90\%.

Протипоказання до вакцинації від грипу включають алергію на білок курячих яєць, алергійні реакції на інші компоненти препарату, тяжкі алергійні реакції на попереднє щеплення, гостре захворювання або загострення хронічної хвороби у день щеплення.

При дотриманні дієвих рекомендацій можна легко уникнути зараження грипом навіть під час епідемії, лише необхідно повноцінно харчуватися, висипатися до 8 год 
на добу, уникати перевтоми - для підвищення опірної здатності організму. Чисті руки є запорукою здоров'я, оскільки віруси потрапляють в організм через рот, ніс та очі. Доцільно дотримуватися принципу соціального дистанціювання - уникати скупчень людей у зимово-весняний період задля зменшення вірогідності контактів 3 інорікованими. Регулярне провітрювання, вологе прибирання помешкання й офрісних приміщень теж є дієвими.

\section{Література}

1. МОЗ України (2016). Оперативна інсормація щодо грипу та ГРВІ [Електронний ресурс]. - Режим доступу: http://moz.gov.ua/ ua/portal/pre_20160219_a.html.

2. WHO: Flu News Europe [Electronic Resource]. - Access mode: http://flunewseurope.org/.

3. Evolutionary complexities of swine flu H1N1 gene sequences of 2009 / [N.K. Sinha, A. Roy, B. Das et al.] // Biochem. Biophys. Res. Communications. - 2009. - Vol. 390, Issue 3. - P. 349-351.

4. Емерджентні і ре-емерджентні вірусні інсекції: глобальна проблема XXI століття / [Л.О. Панченко, С.І. Васіна, І.Н. Звягольська та ін.] // Інфекційні хвороби. - 2015. - № 4 (82). - С. 59-67.

5. Супотницкий М.В. Генетические ограничения эффективности и безопасности массовых вакцинаций населения / М.В. Супотницкий // Актуальная инфректология. - 2015. - № 1 (6). - C. 100-116.

6. Flahault A. Influenza pandemics: past, present and future challenges / A. Flahault, P. Zylberman // Public Health Reviews. - 2010. - Vol. 32, N 1. - P. 319-340.

7. Гриневич О.Й. Грип H1N1: уроки пандемії / О.Й. Гриневич, І.Г. Маркович // Укр. мед. часопис. - 2010. - № 5 (79) - С. 28-32.

8. Мавродій В.М. Вірус-асоційовані пневмонії / В.М. Мавродій, В.Ю. Артеменко // Укр. терапевт. журн. - 2015. - № 1. C. $1-8$.

9. Сидорчук А.С. Роль системи цитокінів у патогенезі грипу / А.С. Сидорчук, Н.А. Богачик, Я.В. Венгловська // Клін. та експер. патол. - 2008. - Т. 7, № 2. - С. 130-133.
10. Москалюк В.Д. Грип. Діагностика, лікування, профрілактика / В.Д. Москалюк. - Чернівці: БДМУ, 2010. - 180 с.

11. Унісікований клінічний протокол первинної медичної допомоги дорослим та дітям, хворим на грип та гострі респіраторні інсрекції. - Київ, 2014. - 25 с.

12. Голубка О.С. Оцінка наслідків тяжких фоорм грипу та летальності серед осіб груп ризику в пандемічному сезоні 20092010 років в Україні / О.С. Голубка, О.В. Онищенко, А.П. Міроненко // Профрілактична медицина. - 2013. - № 3-4 (21). - С. 55-58.

13. Удосконалення лікування хворих на грип та інші ГРВІ / [М.А. Андрейчин, В.С. Копча, В.Д. Москалюк та ін. ] // Інфекційні хвороби. - 2013. - № 2. - С. 12-19.

\section{DIAGNOSTICS AND TREATMENT OF INFLUENZA: CONTEMPORARY CLINICAL AND PATHOGENETIC ASPECTS}

V.D. Moskaliuk, A.S. Sydorchuk

SUMMARY. The results of current virological studies of a global circulation of influenza viruses and their genetic variants had analyzed. Clinical peculiarities of seasonal and pandemic influenza had detailed highlighted. It had emphasized on immune pathogenetic mechanisms of complicated and fatal infection cases. The aspects of effective treatment had discussed with consideration of evidence-based medicine principles. It had underscored the varied prophylaxis principles and prevention of diseases caused by human influenza viruses.

Key words: monitoring, epidemic influenza A/H1N1, virus-associated pneumonias, diagnostics, treatment, evidence-based medicine.

Отримано 10.02.2016 p. 